\title{
Optimizing forage allowance for productivity and weed management in integrated crop-livestock systems
}

\author{
Mauricio Z. Schuster ${ }^{1}$ (D) - Sebastião Brasil Campos Lustosa ${ }^{2}$ - Adelino Pelissari ${ }^{1} \cdot$ Steven Kent Harrison $^{3}$. \\ Reuben Mark Sulc ${ }^{3}$. Leonardo Deiss ${ }^{1}$. Claudete Reisdorfer Lang ${ }^{1}$. Paulo Cesar de Faccio Carvalho ${ }^{4}$. \\ Dionísio Luiz Pisa Gazziero ${ }^{5}$. Anibal de Moraes ${ }^{1}$
}

Accepted: 18 February 2019/Published online: 5 March 2019

(C) INRA and Springer-Verlag France SAS, part of Springer Nature 2019

\begin{abstract}
Weeds are a major constraint on food and feed production, and the excessive use of herbicides to control them is a global concern for food security, human health, and environmental sustainability. Under no-tillage systems, cover crop residues provide a physical barrier to weed emergence that reduce weed infestations and reliance on herbicides. In integrated crop-livestock systems, cover crops provide fodder to grazing animals, adding an additional source of revenue for farmers; however, grazing can cause a trade-off because it reduces biomass during the cover crop season and residues left on the soil surface in the next cash crop, which may increase weed infestation. In the current study, it was hypothesized that there is an optimal cover crop forage allowance during the grazing period that maximizes beef production while retaining enough cover crop biomass and residue to minimize weed infestations and maintain grain yield of the subsequent cash crop. Therefore, the effects of cover crop (mixed black oat + Italian ryegrass) forage allowances (based on sward height) during the winter grazing period on weed infestations, beef production, and soybean grain yield during the next summer season were evaluated. The experiment was conducted in several commercial fields involving two experimental protocols (one short-term and one long-term experiment) in Southern Brazil, and the results demonstrated that a moderate forage allowance in winter cover crops (i.e., maintaining $17.8 \mathrm{~cm}$ of winter grazed cover crop sward height) reduced weed infestations and increased soybean and beef production when compared with a lower forage allowance (i.e., $<10.7 \mathrm{~cm}$ of winter grazed cover crop sward height) or a higher forage allowance (i.e., $>17.8 \mathrm{~cm}$ of winter grazed cover crop sward height). Therefore, the current study provides evidence that it is possible to optimize forage allowance to sustainably intensify arable cropping systems using winter cover crops for direct grazing.
\end{abstract}

Keywords Crop yield $\cdot$ Integrated weed management $\cdot$ Landscape ecology $\cdot$ Sustainable intensification $\cdot$ Weed ecology

Mauricio Z. Schuster

mauricioschus@gmail.com

1 Department of Crop Production and Protection, Federal University of Paraná, 1540 Rua dos Funcionários Road, Curitiba, PR 80035-060, Brazil

2 Department of Agronomy, Midwest State University of Paraná, 03 Simeão Camargo Varela de Sá road, Guarapuava, PR 85040-080, Brazil

3 Department of Horticulture and Crop Science, The Ohio State University, 2021 Coffey Road, Columbus, OH 43210-1086, USA

4 Department of Forage Plants and Agrometeorology, Federal University of Rio Grande do Sul, Porto Alegre, RS 91540-000, Brazil

5 Embrapa Soybean (Brazilian Company of Farming Research Soybean Unit), Londrina, PR 86001-970, Brazil

\section{Introduction}

The world population is projected to increase $34 \%$ by 2050 , generating major concerns about the future of human lifestyles and food security (FAO 2016). A reasonable way to produce enough food and fulfill societal and environmental demands is through sustainable intensification of agricultural production. Many reports have shown that integrated crop-livestock systems (ICLS) can provide synergy between agricultural production and environmental quality (Costa et al. 2019), and these systems are widespread around the world, comprising a total area of approximately 2.5 billion hectares (Keulen and Schuman 2004).

No-tillage management in Brazil is currently practiced on more than $50 \%$ of the area devoted to annual crops and approximately $80 \%$ of the soybean area is no-tilled and usually 
preceded by a winter cover crop (CONAB 2016). No-tillage ensures high productivity and low consumption of fossil fuels while preventing soil erosion and increasing carbon sequestration. In addition, it dramatically reduces the off-farm effects of soil erosion (e.g., road maintenance, water treatment, silting), lowers emissions of greenhouse gases, and improves aquifer recharging by improving rainfall infiltration into the soil (Freitas and Landers 2014).

Cover crops are usually non-marketable plants grown to cover the soil surface. These crops can improve soil fertility and reduce both weed emergence and herbicide dependence (McKenzie et al. 2016). Cover crops can play a critical role in no-tillage crop management systems because the cover crop residues are left on the soil surface and provide a physical barrier to weed emergence. Nevertheless, cover crops with high dry matter production and forage potential can also provide a source of grazing for livestock and thus provide an additional source of revenue for farmers and increase food production per unit area between successive grain crops (Moraes et al. 2014; Nie et al. 2016; Sulc and Franzluebbers 2014). However, many reports indicated that some of the benefits provided by cover crops depend on the amount of residue left on the surface (Webster et al. 2016; Schuster et al. 2018) and grazing of cover crops may have a direct impact on the residual straw amount (Hunt et al. 2016). There is still a lack of information about the minimum sward height of winter grazed cover crops that does not negatively affect weed control benefits, as well as the sward height that promotes high meat production with the best combination of stoking rates and animal performance (Fig. 1). Finally, the question that remains unanswered is if a trade-off exists between high meat production and weed infestation or if it is possible to find a management strategy for a win-win situation in an ICLS.

The current study hypothesized that there is an optimal forage allowance (represented by a specific sward height) of a cover crop that maintains high beef production while still providing enough plant residue to reduce weed infestations in ICLS. This study aimed to evaluate how forage allowances affect winter livestock production and successive summer crop grain yields and to determine the impact of forage allowance on weed infestations in subtropical ICLS.

\section{Materials and methods}

\subsection{Site description}

\subsubsection{Field farm survey}

Field surveys were conducted in a region that contains the oldest ICLS established in Southern Brazil. The experimental sites were located within $300 \mathrm{~km}$ of the city of Guarapuava in Paraná State $\left(25^{\circ} 23^{\prime} 36^{\prime \prime} \mathrm{S}\right.$ latitude, $51^{\circ} 27^{\prime} 19^{\prime \prime} \mathrm{W}$ longitude, and $1200 \mathrm{~m}$ altitude). The sites are dominated by Oxisol soils and are characterized by a humid temperate climate with moderate hot summers (Cfb), according to the Köeppen classification system. Throughout the year, the temperature generally ranges from 8 to $25{ }^{\circ} \mathrm{C}$ and is rarely below $2{ }^{\circ} \mathrm{C}$ or above $28{ }^{\circ} \mathrm{C}$, and the humidity is generally above $70 \%$ and rarely less than $40 \%$. The average annual temperature and precipitation are $18.1^{\circ} \mathrm{C}$ and $1944 \mathrm{~mm}$, respectively.

The survey area included a farmers' network, which was started more than 20 years ago to implement ICLS. Within this long-term network, 26 fields were selected in 2014 in order to characterize sward height management during the grazing period. Those fields had some differences in agronomic history (i.e., soil fertility, agrochemical use, and crop rotation); however, during the winter season in all fields, a mixture consisting of $40 \%$ black oat (Avena strigosa; "common" cultivar) and 60\% Italian ryegrass (Lolium multiflorum; "common" cultivar) was grown to form a mixed winter pasture. Grazing was forage-based in a continuous stocking system with steers (crossbred Angus, Simental, Charolês, and Nellore) weighing $220 \pm 40 \mathrm{~kg}$. Stocking was initiated when the forage height reached $25 \pm 5 \mathrm{~cm}$. In the summer season, soybean (brasmax Apolo RR cultivar) was grown under notillage management and the duration of the grain crop season was 4 months (between November and March). Glyphosate was applied for weed control (described later), and none of the 26 fields received additional weed control measures. All fields were selected from different farms that were at least $1 \mathrm{~km}$ apart, and some had the same owner (farmer). The averaged field area surveyed was 600 ha, with individual field sizes ranging from 50 to 2000 ha. The grazing period usually started in early May and the duration was 4 months.

\subsubsection{Long-term (15 years) ICLS protocol}

The long-term ICLS experiment was conducted on a 22-ha site located on Espinilho Farm (Agropecuaria Cerro Coroado) in São Miguel das Missões, Rio Grande do Sul State, Brazil ( $28^{\circ} 56^{\prime} 12^{\prime \prime} \mathrm{S}$ latitude and $54^{\circ} 20^{\prime} 52^{\prime \prime} \mathrm{W}$ longitude), at an altitude of $465 \mathrm{~m}$ and characterized by a humid temperate climate with a hot summer (Cfa), according to the Köeppen classification system. Throughout the year, the temperature generally ranged from 8 to $29{ }^{\circ} \mathrm{C}$ and was rarely less than $1{ }^{\circ} \mathrm{C}$ or above $34{ }^{\circ} \mathrm{C}$, and the humidity was generally above $60 \%$ and rarely less than $30 \%$. The average annual temperature and precipitation are $19^{\circ} \mathrm{C}$ and $1850 \mathrm{~mm}$, respectively. The soil was an Oxisol (Rhodic Hapludox, Soil Survey Staff 1999). The soybean-beef cattle ICLS was established in 2001 and has maintained the same cropping sequence: (1) mixed pasture cover crop during the winter season (cattle grazing from $\sim$ May to November) and (2) soybean for grain production during the summer season (from $\sim$ December to May). 
Fig. 1 Overall effect of sward height of grazed cover crop in integrated crop-livestock systems (adapted from Carvalho et al. 2005)

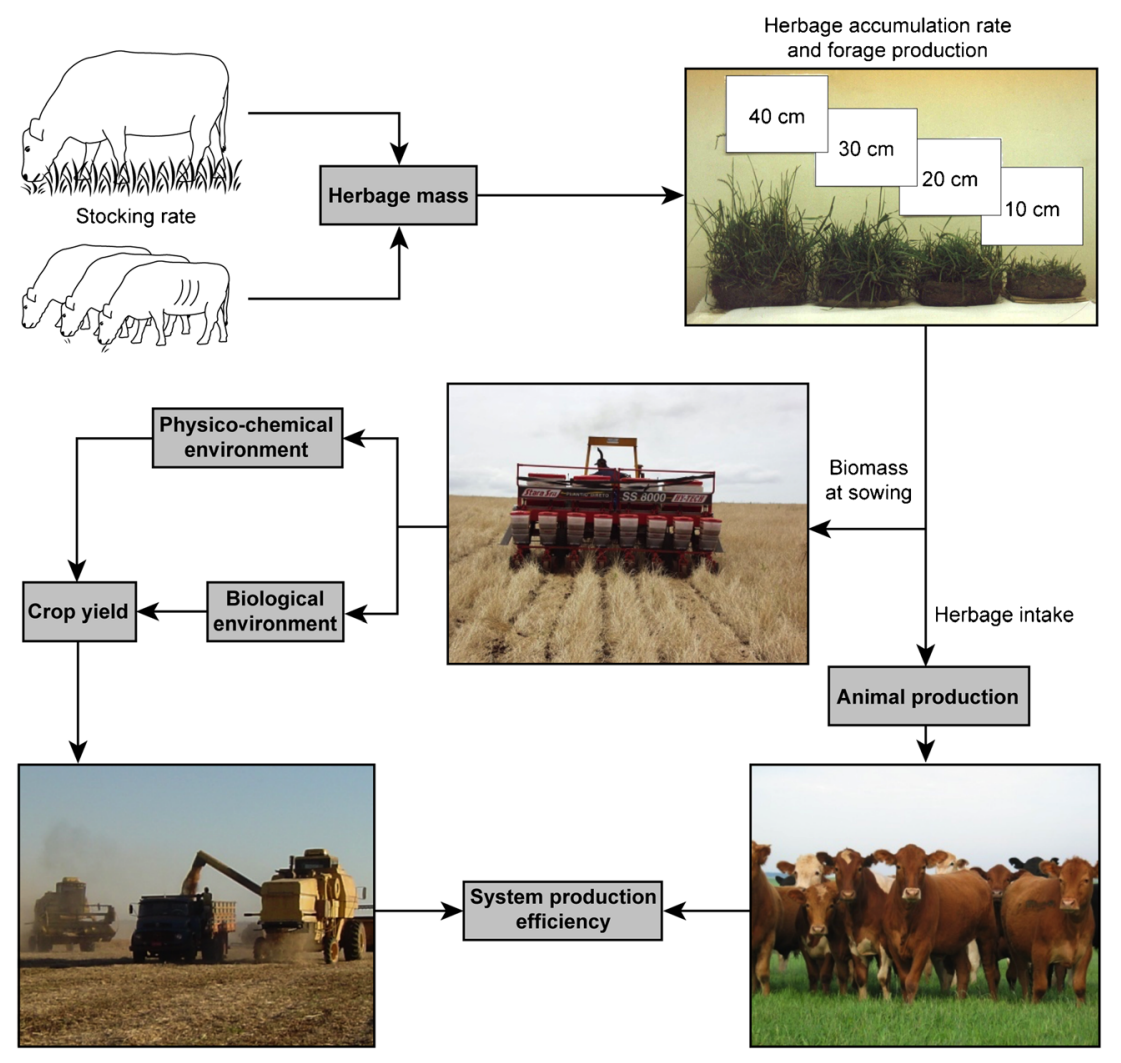

During the winter season, black oat (A. strigosa; Iapar-61 cultivar) was sown (45 $\left.\mathrm{kg} \mathrm{ha}^{-1}\right)$ along with the naturally reseeding $\left(\sim 30 \mathrm{~kg} \mathrm{ha}^{-1}\right)$ Italian ryegrass (L. multiflorum; "common" cultivar) to form a mixed pasture system. The proportion of black oat/Italian ryegrass in the mixture changed throughout the grazing season but averaged $60 \%$ Italian ryegrass and $40 \%$ black oat. Grazing was forage-based in a continuous grazing system, and steers weighing approximately $200 \mathrm{~kg}$ (crossbred Angus, Hereford, and Nellore) entered the pasture system when the forage reached approximately $1.5 \mathrm{t} \mathrm{ha}^{-1}$ of dry matter ( $25 \mathrm{~cm}$ sward height).

Treatments consisted of different sward heights during the winter season, which were determined by pasture vegetation height. Targeted pasture vegetation heights were 10, 20, 30, and $40 \mathrm{~cm}$, and these heights have been maintained since the ICLS was established. All treatments were organized in a randomized block design with three replications, with experimental units ranging from 1.0 to 2.5 ha. Pasture heights were controlled by monitoring sward heights every 14 days using the sward stick method, which consisted of using a graduated measurement stick with a "marker" that slides up and down until the first forage leaf blade is touched. Approximately 100 randomized forage height measurements were taken within each experimental unit. A target average forage height, which corresponded to the desired grazing intensity treatment, was achieved using a put-and-take stocking technique, adding or removing steers from the plot as required.
At the end of the winter season (mid-November), the area was desiccated using glyphosate (application rates were determined as a function of the weed species present and varied from 2400 to $5000 \mathrm{~g}$ a.i. ha ${ }^{-1}$ of glyphosate). In December of each year (summer season), soybean (Nidera 6401RR cultivar) was sown in rows spaced $45 \mathrm{~cm}$ apart using a seeding rate of 45 seeds $\mathrm{m}^{-2}$. Post-emergent glyphosate was applied in mid-January. Soybeans were harvested in May each year.

\subsubsection{Short-term (single year) ICLS protocol}

The ICLS trial experiment was conducted on an 11-ha site located on the Experimental COAMO Farm (Agroindustrial Cooperativa), in Campo Mourão, Paraná State, Brazil (24 $05^{\prime}$ $47^{\prime \prime} \mathrm{S}$ latitude and $52^{\circ} 21^{\prime} 18^{\prime \prime} \mathrm{W}$ longitude). It is at an altitude of $630 \mathrm{~m}$ and has a Cfa climate, according to the Köeppen classification system. Throughout the year, the temperature generally ranges from 13 to $30{ }^{\circ} \mathrm{C}$ and is rarely less than $8{ }^{\circ} \mathrm{C}$ or above $33{ }^{\circ} \mathrm{C}$, and the humidity is generally above $50 \%$ and rarely less than $30 \%$. The annual average temperature is $20{ }^{\circ} \mathrm{C}$, and the annual average precipitation is $1570 \mathrm{~mm}$. The soil is an Oxisol, well-drained, and dark red. Since 1985, no-tillage crop management has been used in the area. The soybean-beef cattle ICLS experiment reported here was conducted for 1 year (i.e., 2002) and established during the following two seasons: (1) winter (cattle grazing from 
June to August) and (2) summer (soybean cropping from $\sim$ October to February).

During the winter season, black oat (A. strigosa; "common" cultivar) and Italian ryegrass (L. multiflorum; "common" cultivar) were planted (60 and $30 \mathrm{~kg} \mathrm{ha}^{-1}$, respectively) to form a mixed pasture. The proportion of black oat/Italian ryegrass changed throughout the grazing season with an average of $60 \%$ of Italian ryegrass and $40 \%$ of black oat. Grazing was forage-based in a continuous stocking system with steers weighing approximately $180 \mathrm{~kg}$ (crossbred Angus, Simental, Charolês, and Nellore) entering the pasture system when the forage height reached approximately $35 \mathrm{~cm}$.

Treatments consisted of different sward heights during the winter season, which were determined by monitoring pasture sward heights every 14 days at approximately 20 random locations within each plot and adjusting the stocking rate as necessary, as described previously for the long-term protocol experiment. Targeted pasture vegetation heights were 7,14 , 21 , and $28 \mathrm{~cm}$. All treatments were organized in a randomized complete block design with four replications, and plots ranged from 0.5 to 1.7 ha.

At the end of the winter season (middle September), the area was desiccated using glyphosate. In mid-October (summer season), soybean (V-Max RR cultivar) was sown in rows spaced $40 \mathrm{~cm}$ apart using a seeding density of 35 seeds $\mathrm{m}^{-2}$. Post-emergent glyphosate was applied in mid-December. Soybeans were harvested in late February.

\subsection{Data collection}

\subsubsection{Weeds}

In the commercial fields, weed communities were surveyed and pasture heights were measured in 2014 within a 50-m $\times 40-\mathrm{m}$ area located $100 \mathrm{~m}$ away from a field boundary to avoid the field edge effects. Weed data were collected in mid-June 2014 (grazing period). The sampling protocol consisted of recording all species occurring within the $2000-\mathrm{m}^{-2}$ area by walking in a "W" pattern within the plot. The average density of each species was estimated using the Barralis scale of six cover abundance classes, described in Fried et al. (2009), where "+" indicates a species found only once in the $2000-\mathrm{m}^{-2}$ area, "l" = less than 1 individual $\mathrm{m}^{-2}, " 2 "=1-2$ individuals $\mathrm{m}^{-2}, " 3 "=3-20$ individuals $\mathrm{m}^{-2}$, "4" $=21-50$ individuals $\mathrm{m}^{-2}$, and " $5 "=50$ 100 individuals $\mathrm{m}^{-2}$. Median values of the abundance class data were determined following the methodology proposed by Trichard et al. (2013). Plants were identified according to Kissmann and Groth (1997) and Lorenzi (2006).

In each experimental unit of the long-term protocol (São Miguel das Missões), weed seedling emergence was quantified for two seasons, at the end of the grazing period (November in 2014 and 2015) and during soybean cropping before postemergent herbicide application (mid-January in 2015 and
2016). The emerged weed seedlings were identified and counted within a $50 \times 50$-cm square placed at 14 -m intervals in the central area of each experimental unit and distributed along four 56$\mathrm{m}$ transects laid out in an "XX" pattern, to ensure an adequate spatial distribution of measurements. We calculated the population density of each species from the individual number of each species per square meter. Plants were identified according to Kissmann and Groth (1997) and Lorenzi (2006).

\subsubsection{Beef production}

In the long-term protocol (São Miguel das Missões), animals were weighed at the beginning and end of the stocking period, as measured after restricting food and water for $12 \mathrm{~h}$. The average daily gain $(\mathrm{kg} / \mathrm{animal})$ was obtained by dividing weight gain by grazing days, and gain per hectare ( $\mathrm{kg}$ live weight/ha) resulted from multiplying the number of animals per hectare and the average daily gain of animals. Stocking rate, expressed in kilograms per hectare, was calculated by adding the average live weight of the tester animals with the average live weight of each "put and take" animal, multiplied by the number of days they remained in each paddock, and then divided by the number of grazing days. Animal performance was also evaluated during this period. Animal coefficients (i.e., average daily gain, gain per hectare, and stocking rate) in the short-term ICLS protocol (Campo Mourão) were determined by the same methods as described for the longterm protocol.

Farmers participating in the study were surveyed by answering a series of closed-ended questions regarding beef production in commercial fields. All participating farmers answered $100 \%$ of questions and had adopted a considerable amount of technology in their operations, including the use of a digital scale for determining animal weights with $0.1 \mathrm{~kg}$ precision. From the farmer questionnaire, we were able to calculate animal coefficients, such as average daily gain and gain per hectare.

\subsubsection{Soybean yield}

In the long-term protocol (São Miguel das Missões), soybean grain yield and final plant population were evaluated in 2015 and 2016, at the R8 growth stage (full maturity). All plants were sampled within a 1.5 linear meter from six random locations per plot. Pods were manually threshed, and the seeds were weighed and the moisture content was measured. Grain yield was adjusted to $13 \%$ moisture content. Crop yields in the trial ICLS experiment (Campo Mourão) were measured by the same methods as described for the long-term protocol, with the exception that 2 linear meters were sampled for each sampling unit and there were ten sampling units per plot. Information about soybean crop yields on commercial fields was collected through the questionnaire described earlier. 


\subsection{Data analysis}

\subsubsection{Weed diversity and evenness analyses}

Shannon's diversity index was estimated for each treatment as follows (Kent and Coker 1992):

$H=\sum_{i=1}^{S}\left(\frac{n i}{N}\right)\left(\log _{2} \frac{n i}{N}\right)$

where $N$ is the total number of individuals per plot, $n i$ refers to the number of individuals per species per plot, and $S$ describes the total number of species.

The evenness of the species $(J)$ in each treatment was also calculated using Shannon's diversity index as follows (Kent and Coker 1992):

$J=\frac{H}{\log _{2}(s)}$

\subsection{Statistical procedures}

The relationships between pasture sward height and weed characteristics, meat production, and crop yield were analyzed using linear, quadratic, exponential, and segmented mixed models. Farmers, fields, or fields nested within farmers were included as random effects in the models (considering both the short-term and long-term protocols as fields with independent farmers). Farmer inclusion assumed a similar effect across the fields farmed by the same farmer; field inclusion assumed variability across the fields, independent of farmers; and, finally, fields nested within farmers assumed variability between fields for a given farmer. On the segmented models, only farmers were used as a random effect, due to the data availability on the segments. The season (winter and summer) was included as a fixed effect when evaluating weed characteristics. Models were selected based on the Akaïke Information Criterion (AIC), and the Likelihood Ratio Test (LRT) was used to test the significance of fixed and random effects. Models were fitted by maximizing the restricted loglikelihood. Data were analyzed using R Version 3.1.0 (C) 2014 The R Foundation for Statistical Computing).

\section{Results and discussion}

Analyzing data from commercial fields comes at the cost of various uncontrolled factors that may increase the variability of responses; however, farm-scale analysis provides strong evidence that the role of managing forage allowances to achieve both lower weed infestation and high soybean and beef production occurs independently of initial conditions (e.g., soil fertility, weed pools, and seed bank size) and uncontrolled factors (e.g., system management and climatic conditions). Furthermore, to strengthen the accuracy of the analysis, the current study used two protocols (shorter- and longer-term experiments) that provided robust data under controlled conditions showing the response occurs in the first year of imposing different forage allowances and that this response is stable across years. Treatment effects were reasonably similar between commercial and experimental fields, but for some of the variables, there was significant variability associated with different fields, farmers, or fields for a given farmer. Regression models were developed under the assumptions described earlier, and the resulting predictions and confidence intervals are shown in Figs. 2a, b, d, 3, and 4a, c).

\subsection{Weed density and diversity in an ICLS}

The impact of winter grazed cover crop sward height on weed characteristics was analyzed over two seasons (winter and summer), across fields from Guarapuava, and the long-term protocol of São Miguel das Missões (Fig. 2). As forage allowance increased (i.e., as winter grazed cover crop sward height increased), the weed density decreased exponentially (Fig. 2a). Weed species richness followed a similar behavior but decreased linearly as winter grazed cover crop sward height increased, and there was significant random variability among fields managed by a given farmer (Fig. 2b). There was no winter grazed cover crop sward height effect on weed diversity (Fig. 2c). Finally, the weed species evenness decreased as winter grazed cover crop sward height increased along with random variability between farmers (Fig. 2d) and the shorter weed species evenness represented an increase in dominant weeds. There was no effect of season on any weed characteristics evaluated, and neither fields nor farmers affected the random variability of the weed density and diversity as winter grazed cover crop sward height varied. Results showed that higher winter grazed cover crop sward height dramatically reduced weed density (Fig. 2a) and maintained weed diversity in ICLS (Fig. 2c) because it improved weed species evenness (Fig. 2d).

A recent report emphasized the role of conserving weed species diversity in arable fields because of diversity's role in supporting ecosystem services (Gaba et al. 2016). Weed presence in croplands stimulates a long-running debate among ecologists, chemical companies, agricultural advisors, and farmers. All of them play a pivotal role in society, but the conflicts regarding herbicide usage invoke issues ranging from maintaining high crop yield, creating risks for environmental quality and food security, and maintaining biodiversity. To help resolve this conflict, alternative weed control methods can play a pivotal role in reducing weed density to a level below economic thresholds while still maintaining weed diversity, thus conserving important ecosystem services, such as feeding pollinators. Based on the result of this study, 


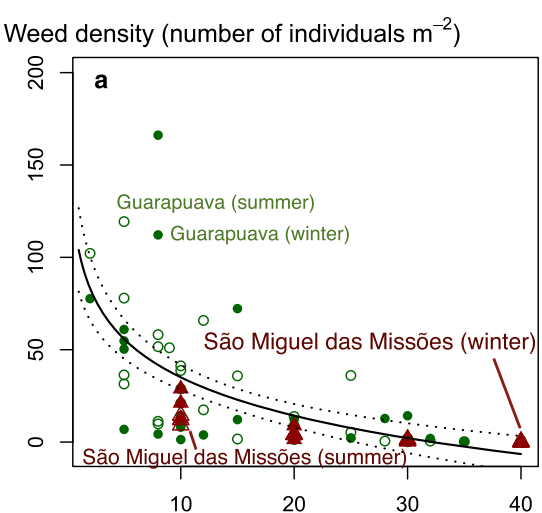

Weed species richness (number of species $\mathrm{m}^{-2}$ )

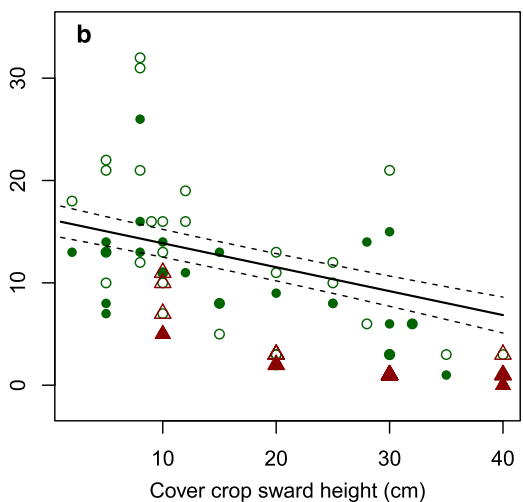

Fig. 2 Changes in winter and summer weed density (a) $(y=104.04[ \pm$ $11.3]-29.96[ \pm 4.02] \times \log (x), p<0.0001, \operatorname{LogLik}=-329.1$, AIC $=$ 664.3, $d f=72)$; weed species richness $(\mathbf{b})(y=14.86[ \pm 1.55]-0.22[ \pm$ $0.04] x, p<0.0001, \operatorname{LogLik}=-201.3, \mathrm{AIC}=414.6, d f=72)$; weed diversity (c) $(y=1.47[ \pm 0.14]-0.012[ \pm 0.006] x, p>0.05$, LogLik $=-$ 73.03, $\mathrm{AIC}=152.1, d f=72)$; and weed species evenness $(\mathbf{d})(y=0.18[ \pm$ $0.06]+0.017[ \pm 0.002] x, p<0.0001, \operatorname{LogLik}=-0.51, \mathrm{AIC}=9.01, d f=$

72) along a forage allowance (maintained grazed cover crop sward

organic and agroecological systems, designed to minimize synthetic pesticide inputs, should consider a taller sward height as a strategy to both reduce potential crop-weed competition and maintain weed diversity.

The relationship between cover crop residue mass and sward height was measured only on the experimental fields from the Campo Mourão ICLS trial and from the long-term protocol of São Miguel das Missões (Fig. 3). The residue mass of grazed or no-grazed (i.e., the highest achieved residue) cover crops was positively and linearly associated with the cover crop sward height. No random effects of fields or farmers were observed for this relationship.

Schuster et al. (2018) showed the importance of straw in reducing weed emergence, which may explain why weed emergence decreased exponentially as the sward height increased (Fig. 2a). To achieve a 50\% reduction in the emergence of herbicide-resistant weeds, which are suppressed by residue additions to the soil surface in no-tillage systems, Webster et al. (2016) found a required residue amount of $5.2 \mathrm{t} \mathrm{ha}^{-1}$ for Amaranthus palmeri suppression, and Schuster et al. (2016)
Weed diversity (Shannon index)

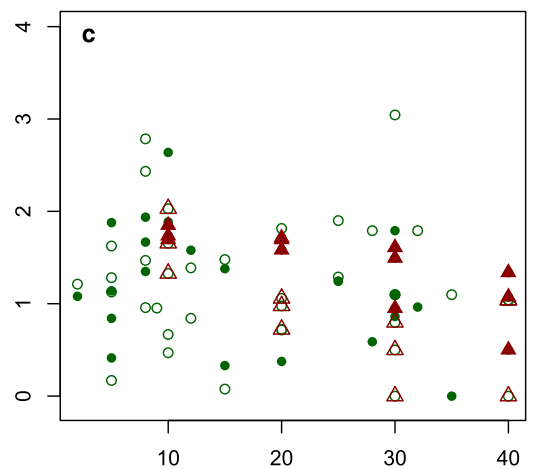

Weed species evenness (Evenness index)

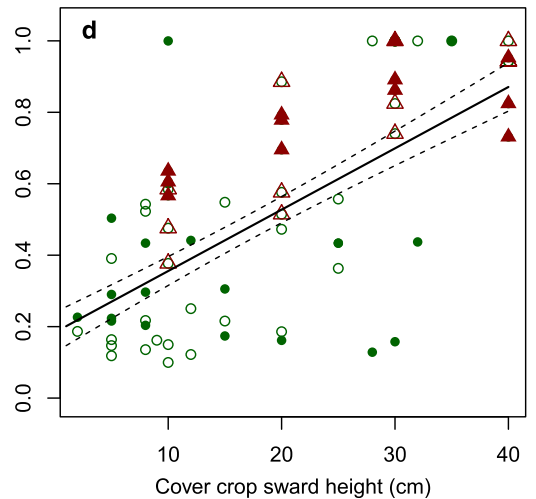

height) gradient in mixed black oat and Italian ryegrass winter cover crop grazed by cattle. Dashed lines represent the 95\% confidence interval. Circles represent farm fields from Guarapuava, empty circles represent summer measurements, and filled circles represent winter measurements. Triangles represent fields from the long-term protocol at São Miguel das Missões, empty triangles represent summer measurements, and filled triangles represent winter measurements

reported a required residue amount of $3.2 \mathrm{t} \mathrm{ha}^{-1}$ for Conyza canadensis suppression. Based on the current results showing that the residue amount is strongly and positively related to the cover crop sward height, maintaining ICLS swards heights of 38 and $23 \mathrm{~cm}$ would be enough to promote $50 \%$ suppression of A. palmeri and C. canadensis emergence, respectively.

\subsection{Beef production in an ICLS}

Beef production and its characteristics were also evaluated as a function of winter grazed cover crop forage allowance, but these variables were analyzed by including fields from the Campo Mourão ICLS trial along with fields from Guarapuava and the long-term protocol of São Miguel das Missões. Live weight gain of beef cattle had a quadratic response to cover crop sward height: increasing up to a maximum as sward height increased to $17.8 \mathrm{~cm}$ but then declining at a taller sward height (Fig. 4a); therefore, maintaining sward heights at $17.8 \mathrm{~cm}$ is optimal to maximize beef cattle production in an ICLS (i.e., $389.9 \mathrm{~kg} \mathrm{ha}^{-1}$ of live weight daily gain; Fig. 4a). Both the 


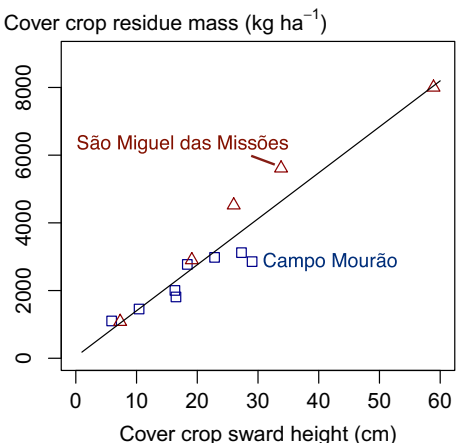

Fig. 3 Changes in cover crop residue mass $\left(\mathrm{kg} \mathrm{ha}^{-1}\right)(y=45[ \pm 330]+$ $135[ \pm 12] x, p<0.0001, \operatorname{LogLik}=-91.2, \mathrm{AIC}=188.5, d f=13)$ in an ICLS along a forage allowance (maintained grazed cover crop sward height) gradient in mixed black oat and Italian ryegrass winter cover crop grazed by cattle. Dashed lines represent the $95 \%$ confidence interval. Squares represent fields from the short-term protocol at Campo Mourão and triangles represent fields from the long-term protocol at São Miguel das Missões

average daily gain of beef cattle (Fig. $4 \mathrm{~b}$ ) and the grazing period (Fig. 4d) showed a similar behavior: increasing up to a maximum as cover crop sward height increased (joint points $15.1 \pm$ 2.7 and $6.7 \pm 1.3$, respectively) but then slightly declined at a taller cover crop sward height. The second slopes of the segmented models were not significantly different from 0 ( $p>0.1$ for both variables). Both segmented responses to winter grazed cover crop forage allowance included significant random variability due to farmers. The beef cattle stocking rate decreased linearly as winter grazed cover crop sward height increased, and there was a random farmer effect (Fig. 4c).

The response of beef cattle production (i.e., live weight gain) in the current study is similar to that reported by Souza Filho et al. (2019). The optimal winter grazed cover crop sward height that resulted in the greatest beef cattle live weight gain was strongly influenced by the average live weight daily gain of beef cattle (Fig. 4b), for which the minimum optimal sward height was $15.1 \pm 2.7 \mathrm{~cm}$ (non-significant second slope), despite an increased stocking rate at lower sward heights (Fig. 4c). It is well known among grazing ecology researchers that animal performance in forage-based grazing is associated with herbage intake. Moreover, Gonçalves et al. (2018) showed that excessively short or excessively tall sward heights could limit daily herbage intake due to difficulties related with herbage bite apprehension. Specifically, shorter sward heights may have had higher proportions of stems + sheaths, which constrain the bite mass. In contrast, taller sward heights might reduce bite mass, and it is considered a complex destabilizing mechanism that can generate detrimental spatial heterogeneity in both sward height and mass (Nunes et al. 2018).

The grazing period in the current study was strongly reduced at very low forage allowances. Pastures managed with short sward heights did not provide the same plant regrowth capacity after grazing as taller sward heights, possibly due to the severe reduction in leaf area and reduced capacity for recovery. Consequently, short sward heights did not allow for a similar grazing period as taller sward heights because of plant exhaustion. Briefly, when plant photosynthesis becomes severely limited due to unavailable leaf area, plants draw on stored energy reserves in roots and other tissues. When the stored energy is depleted, plant growth ceases and rapid regrowth potential is minimized.

World annual meat consumption per capita is $41.9 \mathrm{~kg}$, including bovine, poultry, pig, and ovine meat (FAO 2011), and as the world population is projected to reach 10 billion in 2050 (FAO 2016), several reports suggest that a diet change from meatbased to cereal-based food is required (Cassidy et al. 2013). However, changing diets is not an easy task in many countries around the world because of traditional cultures. According to the current results, winter grazing of a cover crop maintained at an optimum sward height of $17.8 \mathrm{~cm}$ has the potential to provide enough meat on 1 ha to sustain the average annual meat demand of 3.7 persons, according to the FAO average consumption mentioned above (protein source based exclusively on beef) and based on a $40 \%$ dressing percentage of the animals. Considering that only $45 \%$ of global meat production is derived from bovines (FAO 2011), 1 ha of ICLS could provide enough beef for the per capita meat consumption of 8.2 persons.

In Southern Brazil, 19.3 million hectares are being cultivated with summer crops (mostly soybean) under no-tillage management. However, the area cultivated with grain crops during the winter season usually encompasses less than $25 \%$ of the summer-cultivated area, with the remaining area seeded mostly with non-grazed cover crops (CONAB 2016). This implies that there is a large area ( $75 \%$ of 19.3 million hectares) that could be intensified with ICLS, containing grazed cover crops (mostly black oat and ryegrass due to the favorable environmental conditions). Using the best sward height management observations from the current results (i.e., $17.8 \mathrm{~cm}$ ) and assuming an annual meat demand of $41.9 \mathrm{~kg}$ per capita based on the FAO estimate mentioned previously, it would be theoretically possible to provide enough beef to satisfy the annual meat demand of 53.8 million people, if based exclusively on beef, or 119.2 million people if beef provided only $45 \%$ of the meat in a diversified protein diet.

\subsection{Soybean yield in an ICLS}

Summer soybean grain yield was affected by winter grazed cover crop sward height across all the evaluated fields (Fig. 5), and this effect was consistent across years. Soybean grain yield increased with increasing winter grazed cover crop sward height until $10.7 \pm 1.8 \mathrm{~cm}$ but decreased at taller winter grazed cover crop sward heights (second slope was not significantly different from $0, p>0.01$ ), and the response had a random variability due to farmers. Thus, the optimal cover crop sward height in winter that resulted in the greatest soybean yield the following summer was taller than $10.7 \pm 1.8 \mathrm{~cm}$ (Fig. 5). 

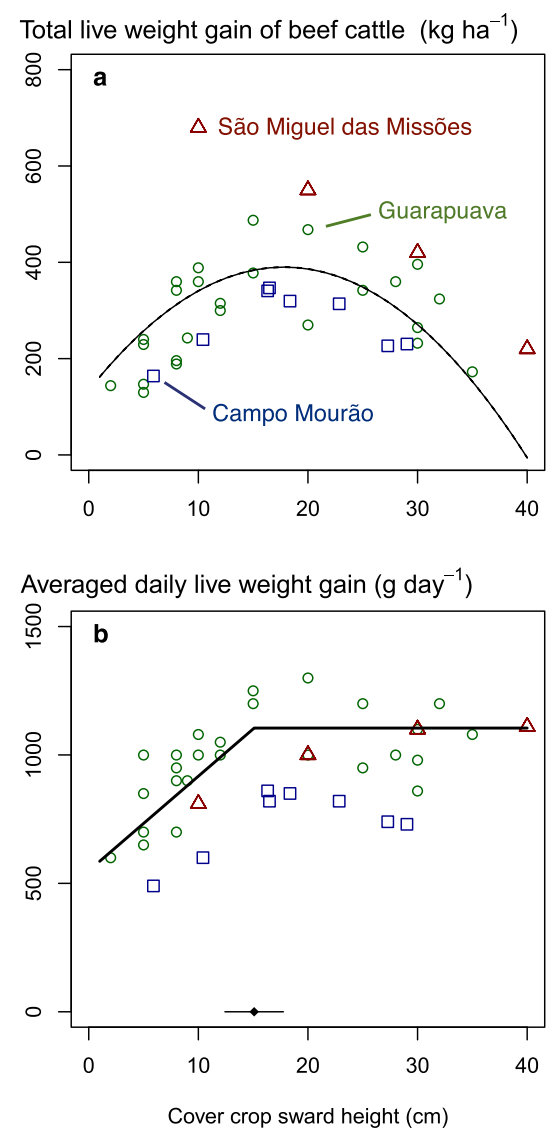

Fig. 4 Changes in cattle live weight gain (a) $(y=134[ \pm 43]+28[ \pm 4.6]$ $\left.x-0.80[ \pm 0.10] x^{2}, p<0.0001, \operatorname{LogLik}=-262.7, \operatorname{AIC}=593.3, d f=46\right)$; average daily gain (b) $(y=549.1+36.8 x$ for $x \leq 15.09[ \pm 2.67], y=$ 1104.62 for $x>15.09$ [ \pm 2.67$], p<0.0001, \operatorname{LogLik}=-271.1$, AIC $=$ 560.7, $d f=46)$; stocking rate $(\mathbf{c})(y=1285[ \pm 48]-23.5[ \pm 1.97] x$, $p<0.0001, \operatorname{LogLik}=-287.0$, AIC $=581.9, d f=46)$; and grazing period (d) $(y=11.61+12.21 x$ for $x \leq 6.68[ \pm 1.33], y=93.17$ for $x>6.68[ \pm$ 1.33], $p<0.0001, \operatorname{LogLik}=-166.8, \mathrm{AIC}=348.7, d f=46)$ along a

Grazed cover crops provide a direct source of revenue for farmers (McKenzie et al. 2016); however, farmers still have concerns about the consequences of grazing on subsequent crop yields. The positive and negative implications of grazing cover crops in ICLS are well-established. Moraes et al. (2014) reviewed 23 papers that evaluated grain yields from crops in succession with winter grazed cover crops (mostly black oat and Italian ryegrass mixture), and most of these studies showed greater summer grain yields in grazed areas than in non-grazed areas. However, a few studies that managed winter pastures with lower forage allowances (i.e., $<12 \mathrm{~cm}$ sward height for black oat and Italian ryegrass mixture) did not have the same positive responses on summer crop grain yields, possibly because of grazing-associated problems, such as soil compaction and nutrient depletion. The current results agree that black oat and Italian ryegrass pastures managed with a sward height less than $12 \mathrm{~cm}$ resulted in severe negative consequences for both soybean yields and beef production.
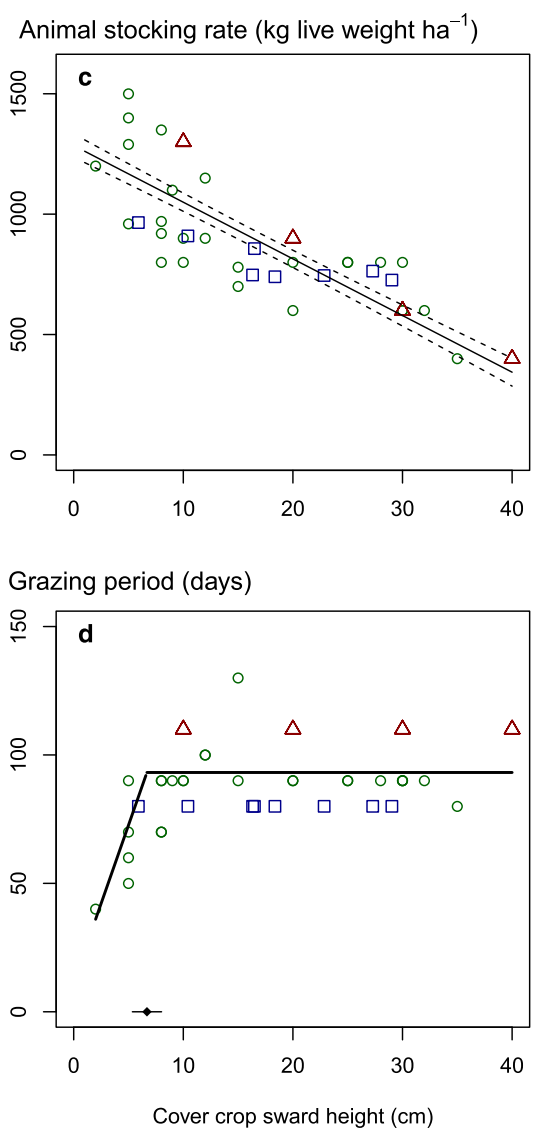

forage allowance (maintained grazed cover crop sward height) gradient in mixed black oat and Italian ryegrass winter cover crop grazed by cattle. Dashed lines represent the $95 \%$ confidence interval. Diamonds on $x$-axes represent break points, and its associated horizontal bars denote standard errors. Circles represent farm fields from Guarapuava, squares represent fields from the short-term protocol at Campo Mourão, and triangles represent fields from the long-term protocol at São Miguel das Missões

Beyond the factors already stated above about the reduction in grain yields promoted by sward heights lower than $12 \mathrm{~cm}$, taller sward heights correspond to a smaller cattle load, and as a consequence, more cover crop residues are left on the soil surface at the end of the grazing season. Greater residues increase soil coverage and promote other advantages often related to no-tillage systems (e.g., greater water retention and reduced weed emergence). Moreover, moderate forage allowances (i.e., $>17.8 \mathrm{~cm}$ sward height, according to the current results) can result in improved soil quality for subsequent crops and improved nutrient cycling in the entire ICLS (Sulc and Franzluebbers 2014). This emphasizes that the magnitude of these benefits is often determined by the grazing intensity, and it is intrinsically related to the flux of organic mass and energy among the soil-plant-animal-atmosphere components.

Cassidy et al. (2013) proposed to re-examine agricultural productivity as the number of people fed per hectare rather than tons of yield per hectare, so the author used the available 


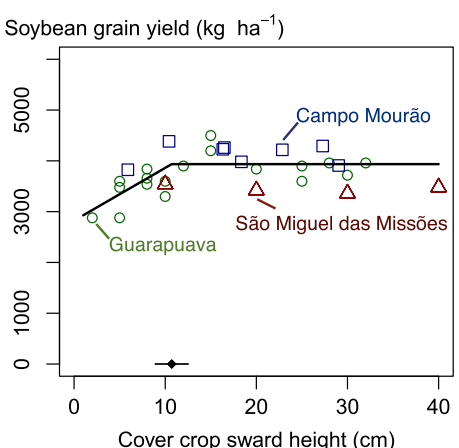

Fig. 5 Summer soybean grain yield response $(y=2824+103.7 x$ for $x \leq$ $10.7[ \pm 1.82], y=3935$ for $x>10.7[ \pm 1.82], p<0.0001, \operatorname{LogLik}=-$ 243.0, $\mathrm{AIC}=501.7, d f=38$ ) to a forage allowance (maintained grazed cover crop sward height) gradient in mixed black oat and Italian ryegrass winter cover crop grazed by cattle. Circles represent farm fields from Guarapuava, squares represent fields from the short-term protocol at Campo Mourão, and triangles represent fields from the long-term protocol at São Miguel das Missões

food calories from crops that nourish people (which is 985,500 or 2700 cal per person per year or day, respectively). If beef and soybean were used exclusively for direct human consumption, and based on energy values of $2445 \mathrm{cal} / \mathrm{kg}$ for beef and $3596.5 \mathrm{cal} / \mathrm{kg}$ for soybean (Cassidy et al. 2013), the current results showed it is theoretically possible to feed 14.2 people per hectare per year. Furthermore, $21.1 \%$ more people could be fed using the optimal grazing sward height of $17.8 \mathrm{~cm}$ compared to the shortest sward height of $2 \mathrm{~cm}$. Finally, this study concerns an area of great interest for world food security regarding major crops and cultivated pastures (i.e., soybean and mixed black oat + Italian ryegrass), and the current results have important implications for sustainable intensification, once the fact that use correct forage allowances to ensure both low weed infestation and the production efficiency of the entire system.

\section{Conclusion}

Overall results suggest that closely managing forage allowances (and thus sward height) during the grazing phase of ICLS is a key component for meeting the goal of reducing weed infestation while maximizing beef and soybean production. Specifically, using a moderate forage allowance (i.e., maintaining a 17.8-cm sward height) in a winter cover crop of black oat and Italian ryegrass in ICLS allowed significant reductions in weed infestations and significant increases in soybean yield and beef production when compared with lower forage allowances in ICLS (i.e., $<10.7 \mathrm{~cm}$ pasture sward height). It is important to highlight the need of multidisciplinary approaches to deal with animal and crop components to investigate ICLS. Future studies will need to advance on how grazing animals in pasture phase connect to plant dynamics on crop phase with consequential emerging processes.
Acknowledgements This study was financed in part by the Coordenação de Aperfeiçoamento Pessoal de Nível Superior, Brasil (CAPES) Finance Code 001. The authors are grateful for the help provided by Celso Roloff during collecting samples in the field.

\section{Compliance with ethical standards}

Conflict of interest The authors have no conflicts of interest to declare.

Publisher's note Springer Nature remains neutral with regard to jurisdictional claims in published maps and institutional affiliations.

\section{References}

Carvalho PCF, Anghinoni I, Moraes A et al. (2005) O estado da arte em integração lavoura-pecuária. In: Proceedings of Produção animal: mitos, pesquisa e adoção de tecnologia. ULBRA, Canoas

Cassidy ES, West PC, Gerber JS, Foley JA (2013) Redefining agricultural yields: from tonnes to people nourished per hectare. Environ Res Lett 8(3):034015. https://doi.org/10.1088/1748-9326/8/3/034015

CONAB (2016). Acompanhamento da safra Brasileira-grãos: monitoramento agrícola-Safra 2016/17. National Supply Company. www.conab.gov.br/info-agro/safras/graos. Accessed 23 January 2019

Costa NB, Baldissera TC, Pinto CE et al (2019) Public policies for low carbon emission agriculture foster beef cattle production in southern Brazil. Land Use Policy 80(1):269-273. https://doi.org/10.1016/j. landusepol.2018.10.014

FAO (2011) Food outlook: global market analysis. Food and Agriculture Organisation, Rome www.fao.org/docrep/014/a1978e/a1978e00.pdf. Accessed 23 January 2019

FAO (2016) How to feed the world in 2050. Food and Agriculture Organisation, Rome www.fao.org/fileadmin/templates/wsfs/docs/ expert_paper/How_to_Feed_the_World_in_2050.pdf. Accessed 23 January 2019

Freitas PL, Landers JN (2014) The transformation of agriculture in Brazil through development and adoption of zero tillage conservation agriculture. Int Soil Water Conserv Res 2(1):35-46. https://doi.org/10. 1016/S2095-6339(15)30012-5

Fried G, Chauvel B, Reboud X (2009) A functional analysis of largescale temporal shifts from 1970 to 2000 in weed assemblages of sunflower crops in France. J Veg Sci 20(1):49-58. https://doi.org/ 10.1111/j.1654-1103.2009.05284.x

Gaba S, Reboud X, Fried G (2016) Agroecology and conservation of weed diversity in agricultural lands. Bot Lett 163(4):351-354. https://doi.org/10.1080/23818107.2016.1236290

Gonçalves RP, Bremm C, Moojen FG, Marchi D, Zubricki G, Caetano LAM, Neto AB, Carvalho PCF (2018) Grazing down process: the implications of sheep's ingestive behavior for sward management. Livest Sci 214(4):202-208. https://doi.org/10.1016/j.livsci.2018.06.005

Hunt JR, Swan AD, Fettell NA, Breust PD, Menz ID, Peoples MB, Kirkegaard JA (2016) Sheep grazing on crop residues do not reduce crop yields in no-till, controlled traffic farming systems in an equiseasonal rainfall environment. Field Crop Res 196(2):22-32. https:// doi.org/10.1016/j.fcr.2016.05.012

Kent M, Coker P (1992) Vegetation description and analysis: a practical approach. Belhaven Press, London

Keulen H, Schuman H (2004) Crop-livestock system: old wine in new bottles? In: New directions for a diverse planet. Proceedings of the IV International Crop Science Congress, Australia, pp. 1-12

Kissmann and Groth (1997) Plantasinfestantes e nocivas. BASF, São Paulo 
Lorenzi HM (2006) Manual de Identificação e Controle de Plantas daninhas. Instituto Plantarum, São Paulo

McKenzie SV, Goosey HB, O'Neill KM et al. (2016) Integration of sheep grazing for cover crop termination into market gardens: Agronomic consequences of an ecologically based management strategy. Renew Agric Food 643 Syst 32(5):389-402. https://doi.org/10. 1017/S1742170516000326

Moraes A, Carvalho PCF, Lustosa SBC et al (2014) Research on integrated crop-livestock systems in Brazil. Rev Ciênc Agron 45(5): 1024-1031. https://doi.org/10.1590/S1806-66902014000500018

Nie Z, McLean T, Clough A, Tocker J, Christy B, Harris R, Riffkin P, Clark S, McCaskill M (2016) Benefits, challenges and opportunities of integrated crop-livestock systems and their potential application in the high rainfall zone of southern Australia: a review. Agric Ecosyst Environ 235(4):17-31. https://doi.org/10.1016/j.agee. 2016.10.002

Nunes PAA, Bredemeier C, Bremm C et al (2018) Grazing intensity determines pasture spatial heterogeneity and productivity in an integrated crop-livestock system. Grassl Sci 65(1):49-59. https://doi. org/10.1111/grs.12209

Schuster MZ, Pelissari A, de Moraes A, Harrison SK, Sulc RM, Lustosa SBC, Anghinoni I, Carvalho PCF (2016) Grazing intensities affect weed seedling emergence and the seed bank in an integrated croplivestock system. Agric Ecosyst Environ 232(17):232-239. https:// doi.org/10.1016/j.agee.2016.08.005
Schuster MZ, Harrison SK, Moraes A et al (2018) Effects of crop rotation and sheep grazing management on the seedbank and emerged weed flora under a no-tillage integrated crop-livestock system. J Agric Sci 156(6):810-820. https://doi.org/10.1017/S0021859618000813

Soil survey staff (1999) Soil taxonomy: a basic system of soil classification for making and interpreting soil surveys. Government Printing Office, Washington

Souza Filho W, Nunes PAA, Barro RS et al (2019) Mitigation of enteric methane emissions through pasture management in integrated croplivestock systems: trade-offs between animal performance and environmental impacts. J Clean Prod 213(3):968-975. https://doi.org/10. 1016/j.jclepro.2018.12.245

Sulc RM, Franzluebbers AJ (2014) Exploring integrated crop-livestock systems in different ecoregions of the United States. Eur J Agron 57(1):21-30. https://doi.org/10.1016/j.eja.2013.10.007

Trichard A, Alignier A, Chauvel B, Petit S (2013) Identification of weed community traits response to conservation agriculture. Agric Ecosyst Environ 179(16):179-186. https://doi.org/10.1016/j.agee. 2013.08.012

Webster TM, Simmons DB, Culpepper AS, Grey TL, Bridges DC, Scully BT (2016) Factors affecting potential for Palmer amaranth (Amaranthus palmeri) suppression by winter rye in Georgia, USA. Field Crop Res 192(8):103-109. https://doi.org/10.1016/j.fcr.2016. 04.020 